Ключевые слова: модель педагогической подготовки, компетентностный подход, национальные колледжи, рынок образовательных услуг, инновационныле технологии, формы организации образовательного процесса, методы обучения, педагогчческая практика.

BIHUN OLEKSANDR, RozSOKHA ANTONINA. The model of pedagogical training of future secondary school teachers in the national colleges.

The leading trend in the development of modern society is the integration of education systems into a single European and world educational space. At the same time, the teacher was still decisive in the implementation of school reforms. In this context, the problem of pedagogical teacher training becomes a scientific expediency and social timeliness. The pedagogical training of future secondary school teachers should be aimed at the formation of specialists with the newest type of thinking, who will provide training and education of a holistic personality, focused on individual self-realization.

The research backgrounds the structural and functional model of the system of pedagogical training of future secondary school teachers in the national colleges. By means of the modeling method, the basic components of pedagogical training are singled out and analyzed: methodological, substantive, procedural, organizational, technical, practical.

It has been ascertained that the model of pedagogical training of future secondary school teachers in colleges is a complex of interrelated elements of the pedagogical process which provide the formation of the system of qualities, knowledge, abilities and skills that are necessary for the successful pedagogical activities. The emphasis in the paper is placed on the importance of the competency-based approach in future teachers training, the formation of a system of value orientations related to the professional activity, ensuring the continuity and variability of pedagogical practice, outlining the criteria for the readiness of a future teacher to professional activities. The introduction of modern approaches to training a competent teacher of a new generation is highlighted, which, in its turn, presupposes changes in the content, methods and forms of the organization of the educational process in the teacher training institutions of Ukraine.

Keywords: model of pedagogical training, competency-based approach, national colleges, market of educational services, innovative technologies, forms of organization of the educational process, learning tools, pedagogical practice.

DOI: https://doi.org/10.31392/NZ-npu-143.2019.06

УДК 378.147: 81'243-021.464

Бреславець Н. О.

\title{
МЕТОДИЧНІ ДІЇ В ЗДІЙСНЕННІ ПРОЦЕСУ НАВЧАННЯ IHОЗЕМНИХ МОВ 3 АКЦЕНТОМ НА САМОСТІЙНУ РОБОТУ СТУДЕНТІВ
}

\footnotetext{
Фактор особистісного зростання людини в XXI виходить на перший план мотиваційних устремлінь молодого покоління: свобода пересування по всьому світу, взаємопроникнення економік, міжнародний поділ прачі, інтенсифікаиія процесу торгівлі та ін. Це є викликами сучасності, щуо різко стимулюють вивчення іноземних мов та вимагають глибоких $і$ якісних змін викладання іноземної мови в середній та вищій школі.

У сучасних умовах самостійність стає професійно необхідною якістю особистості будьякого спеціаліста. Таким чином, підготовка майбутніх спеціалістів у вищому навчальному закладі має орієнтуватися на формування у студентів иієї якості. Вираження самостійності
} 
особистості - вчинки, дії, висловлювання, оцінка особистості стосовно як тих, хто оточує, так і самої себе; самостійність виявляється в результатах діяльності, у характері становлення до довкілля $і$ спрямованості поведінки. У світлі сучасної освітньої конщепції особливого сенсу набуває процес самоосвіти як засобу розвитку творчої індивідуальності, збереження людської гідності, спосіб “вбудовування себе” в соиіокультурний процес, у суспільство.

В умовах реформування національної системи вищої освіти питання наукової організачії навчально-виховного прочесу набуває особливого значення, оскільки передбачає не лише визначення якості підготовки фахівців, а й забезпечує майбутнє економіки. Самостійна робота студента під контролем $і$ без контролю викладача повинна розглядатися як важлива частина всіх складових навчального прочесу, забезпечуватися навчальними та науковими розробками, матеріально-технічною базою, мати високу мотивацію.

Ключові слова: методологічна технологія, самостійна робота студентів, суб'єктність, визначення иілей, планування, саморегуляція дій, самоконтроль.

Процеси глобалізації, що відбуваються в сучасному світовому співтоваристві, демократизація соціокультурного простору українського суспільства, конфлікти, які періодично виникають, і розбіжності з політичних, національних, релігійних та інших питань у різних регіонах земної кулі висувають нові вимоги до національної системи вищої освіти щодо формування і розвитку багатомовної комунікативної особистості професіонала, здатної долати кризові ситуації, орієнтованої на конструктивно-відтворювальну діяльність.

Суб'єктивна позиція і навчальна діяльність студентів формує інтегральну модель випускника вузу, чому сприяє розвиток здібностей до визначення цілей, планування, саморегуляції дій і їх виконання, до самоконтролю та рефлексії. В процесі іншомовної освіти формується іншомовна комунікативна компетентність, що містить комунікативний, когнітивний, діяльнісний та соціокультурний компоненти. Навчання у ЗВО призводить до поступового підвищення рівня суб'єктності у використанні іноземної мови, починаючи від вузьконавчальних до широкопрофрільних комунікативних і професійних рівнів; відбувається поступове ускладнення завдань модельованих мовних ситуацій, що вимагають участі в різних видах діяльності.

Володіння іноземною мовою розширює сферу комунікативних дій, що передбачають можливість активного спілкування як засобу розуміння інших і себе самого, засоби взаємодії. Пізнавальне спілкування сприяє реалізації функції мислення і самовираження. Активне спілкування іноземною мовою в умовах природного спілкування та різних видів діяльності забезпечує підвищення рівня володіння і вдосконалення іноземною мовою.

Формуванню іншомовної компетентності приділяють увагу багато вчених Л. Бім, Н. Д. Гатальскова, Н. І. Гез, С. В. Калініна, І. В. Кочергін, М. В. Ляховицький, О. О. Миролюбов, Ю. І. Пассов, В. Л. Скалкін, С. П. Шатілов та ін.

Специфічною особливістю оволодіння іноземною мовою $є$ ії подвійність (з одного боку - вивчення мовної структури, з другого - розвиток мовлення), вимагає пошуку оптимальних методів навчання з урахуванням психологічних фракторів розвитку мови і свідомого оволодіння лінгвістичними структурами.

Більш досконалим видом використання іноземної мови $є$ ускладнення розумової діяльності від репродуктивного до продуктивного, творчого, від простого відтворення готових думок, висловлених іншими людьми, до здатності 
міркувати, аналізувати, приймати рішення. Репродуктивна діяльність 3 відтворення інформації використовує можливості пам'яті, наприклад, при виконанні граматичних вправ, застосуванні пройденого лексичного матеріалу тощо. Продуктивна діяльність самостійного застосування набутих знань спрямована на вирішення завдань, що виходять за межі досліджуваних проблем, наприклад, при підготовці рефератів, проектів і презентацій, дослідження складних теоретичних питань, вимагає великого обсягу інформації, “стислої” за принципом системності, використання індуктивних і дедуктивних методів роботи, які розвивають вміння аналізувати, порівнювати, узагальнювати, класифікувати.

Діяльність передбачає наявність суб'єкта, суб'єктна позиція людини визначає якісне виконання діяльності. Від характерологічних чеснот суб'єкта залежить ступінь ефективності використання людиною своїх індивідуальних і особистісних ресурсів. У навчальному процесі, що становить акт діяльності, проявляються властивості особистості, суб'єктність його дій. Формування компетентності в певному виді діяльності означає тісний зв'язок всіх цих сорер і процесів накопичення знань, навичок і умінь щодо здатності вільного використання досвіду, способів і засобів у своїй діяльності. Освоєння кожним різноманітних способів виконання універсальних навчальних дій сприяє становленню особистості і суб'єктності людини, яка розвивається, створення своєї особистісної культури.

У сучасних умовах самостійність стає професійно необхідною якістю особистості будь-якого спеціаліста. Таким чином, підготовка майбутніх спеціалістів у вищому навчальному закладі має орієнтуватися на формування у студентів цієї якості. Вираження самостійності особистості - вчинки, дії, висловлювання, оцінка особистості стосовно як тих, хто оточує, так і самої себе; самостійність виявляється в результатах діяльності, у характері становлення до довкілля і спрямованості поведінки.

Самостійна особистість ставить перед собою цілі щодо власної сутності, володіє ініціативністю, має потребу приймати та здійснювати особисті рішення, готова нести відповідальність за їх практичне втілення, за свої дії. Самостійна людина здатна визнавати свої помилки на підставі самокритичного аналізу, рефлексивно приймати певні адекватні рішення, що ведуть до вирішення проблем. Отже, "самостійність - це інтегративна якість особистості, що полягає в здатності та потребі приймати й реалізувати рішення з власної ініціативи і нести за них відповідальність" (Н.І.Дідусь).

У світлі сучасної освітньої концепції особливого сенсу набуває процес самоосвіти як засобу розвитку творчої індивідуальності, збереження людської гідності, спосіб “вбудовування себе” в соціокультурний процес, у суспільство.

Інноваційний підхід в освіті передбачає активну позицію самого учня в процесі набуття знань, самостійний пошук їх i застосування в практичній діяльності. В освітньому процесі студент повинен не тільки набути знання та вміння, а й сфрормувати здатність самостійно мислити, мотивовано і свідомо здійснювати відповідні обстановці дії і операції в динамічно мінливих соціокультурних і виробничих умовах, чому сприяє організована самостійна робота у ЗВО.

Самостійна робота - комплекс заходів, специфічна фрорма навчальної діяльності студента в процесі професійної підготовки з включенням навчально- 
пізнавальної, науково-дослідної та практичної діяльності, які призводять до розвитку здатності до професійно-особистісного саморозвитку, готовності до вирішення складних завдань (Л.Д. Воєводін, О.Л.Жук, В.І. Звонніков, А.П. Лобанов, В.Б. Пальчевський, С. М. Сіренко, Н. М. Токаревіч та ін.). Самостійна робота студентів у вищому навчальному закладі передбачає такі види діяльності:

- пошук та вивчення додаткової літератури;

- конспектування, складання планів, тез;

- кодування інформації (складання схем, таблиць, графріків);

- написання рефератів, доповідей, оглядів, звітів;

- виступ з повідомленнями на семінарських заняттях;

- виконання вправ, розв'язання задач;

- виконання письмових контрольних робіт;

- виконання завдань за допомогою ПЕОМ.

Вищий, творчий рівень розвитку самостійності полягає в потребі постійно ставити перед собою нові цілі та завдання, спрямовані на вихід за межі заданого, на пошук і відкриття нових закономірностей та способів вирішення.

Під час вибору проблем слід керуватися такими критеріями:

- провідні ідеї, поняття, методи науки, боротьба ідей, дискусійні положення та пошук шляхів їх вирішення в історії науки;

- суперечності, невирішені питання сучасної науки, нові технології, що виникають на практичних заняттях або у виробничій практиці [7, с. 157-167].

Різноманіття видів діяльності з використанням іноземної мови, підвищення рівня суб'єктності учня розширюють рамки навчальної діяльності, призводять до методичної інтерпретації навчальних дій; моделюються різні мовні ситуації, розробляються індивідуальні освітні програми, поступово ускладнюються вправи і завдання.

Необхідно представляти досліджувані теми в динаміці, показуючи можливі зміни в часі; розкривати різноманіття зв'язків і смислів як всередині певної теми, так і на міжтематичному рівні, змушуючи використовувати власний досвід і досвід інших; стимулювати власні роздуми, шукати шляхи і підходи для вирішення тих чи інших проблем; знаходити суперечливі теми, фрормулювати різні думки і відстоювати їх. Інформація, що викликає сумніви, повинна ретельно аналізуватися; необхідно навчитися обґрунтовувати протилежні думки в процесі діяльності, залучати нові фракти, робити узагальнення, надаючи нового змісту предмету, що досліджується.

У процесі навчання іноземної мови необхідно викликати у студентів емоційно-ціннісне ставлення до досліджуваного предмета, фрормувати власну обґрунтовану позицію, наповнену особистісним змістом, що сприяє розвитку іншомовної мовленнєвої діяльності.

При вивченні іноземної мови необхідно розвивати здібності учня використовувати іноземну мову як засіб змістовного міжособистісного спілкування з однолітками та колегами в професійній діяльності; як засіб спілкування із самим собою у внутрішній мові в процесі розумової діяльності, при оволодінні способами творчого і критичного мислення, для вирішення різних морально-етичних і соціальних проблем. 
Завдяки внутрішньому мовленню відбувається смислова організація своїх думок, переробка та підготовка їх до майбутнього вислову. Аналізуючи складність проблемної ситуації, готуючи виступ, студент вдається до внутрішнього фрормування думки, внутрішніх роздумів і мобілізує досвід, знання, мовні засоби для точного вираження своїх думок, аргументації своєї позиції. За внутрішньою мовою слідує зовнішня мова іноземною мовою. Постійні розумові процеси підвищують якість оволодіння іноземною мовою, удосконалюючи механізми розумової діяльності. Тому педагогу важливо спонукати учня до внутрішнього діалогу-роздуму із застосуванням іноземної мови та подальшої зовнішньої мовної взаємодії 3 оточуючими, що дає можливість аналізувати, аргументувати, зіставляти, відстоювати свою думку з використанням мовних засобів іноземної мови. Самостійна робота студентів у навчальному процесі характеризується дієвим параметром, що означає самоврядування навчальною діяльністю (від постановки мети до самоконтролю результату навчальної діяльності), критичну рефлексію процесу навчальної діяльності, самооцінку і самореакцію навчальної діяльності (як результату, так і способів навчальної діяльності, що використовуються). Крім того, особистісним параметром, що передбачає прийняття незалежних рішень щодо навчальної діяльності, прийняття відповідальності за результат навчальної діяльності, усвідомлення досвіду навчальної діяльності, незалежність, самостійність визначається позицією “я - вчитель".

Таким чином, однією з освітніх завдань $\epsilon$ розвиток автономії учня в навчальній діяльності, що вимагає цілеспрямованої роботи з формування технологічної сторони навчальної діяльності, розробки ії̈ навчально-методичного забезпечення, розвитку особистісних характеристик, що забезпечують можливість конструктивної, творчої реалізації суб'єкта навчальної діяльності.

У сучасній педагогічній науці самостійна робота студента розглядається як навчальна діяльність, індивідуальна форма навчання, дидактичний засіб вищої школи. Самостійну роботу студента можна розглядати як метод навчання, прийнятий у вищій освіті, і засобом індивідуалізації процесу навчання у вигляді навчальної діяльності на основі різних фрорм партнерських відносин між викладачем і студентом.

Сучасний підхід до вивчення іноземної мови свідчить про необхідність розробки і впровадження певних методів, які допомогли б викладачеві вузу індивідуалізувати навчання, а студенту дали б можливість усвідомити свою відповідальність за процес набуття знань і організувати його в потрібному для нього руслі відповідно до його індивідуальних особливостей і потреб. Потрібно враховувати, що кожен, кого навчають, відрізняється від іншого як за здатністю до вивчення мови, так і за стилем пізнання, мотивації тощо. Крім цього, до вищих навчальних закладів приходять люди з різним рівнем знань, які пройшли навчання за різними програмами, що створює додаткові труднощі для викладання і потребує забезпечення індивідуального підходу.

Одним з основних положень сучасної мовної політики, зокрема і в галузі іноземних мов, $є$ спрямованість на розвиток особистості учня як активного суб'єкта навчальної діяльності та всебічної підготовки його до безперервного процесу освіти, саморозвитку та самовдосконалення.

Одним із сучасних методів навчання $є$ процес самонавчання або самоосвіти 
(self-access learning). Суть його полягає в тому, що студентам надається можливість вибирати і використовувати навчальні матеріали, а також виправляти і оцінювати свою роботу. Така самостійна робота може проходити поза аудиторним навчанням або бути його частиною.

У зарубіжній теорії практики викладання іноземних мов виділяється концепція автономії учня і автономного / самоврядного навчання. Важливою освітньою метою в сучасних програмах з іноземних мов $є$ розвиток самостійної автономії у навчальній діяльності.

Основоположником цієї концепції $€ \mathrm{X}$. Халек, який запропонував це визначення в галузі вивчення іноземних мов. Автономія студента в його розумінні- це вміння брати на себе відповідальність за свою навчальну діяльність, включаючи всі компоненти цієї діяльності, а саме: встановлення цілей, визначення змісту і послідовності, вибір методів і прийомів, оцінка отриманого результату. Особистісними характеристиками студента в автономній освітній діяльності $€$ прийняття незалежних рішень щодо навчальної діяльності, самооцінка і самореакція навчальної діяльності, прийняття відповідальності за результат навчальної діяльності, усвідомлення досвіду навчальної діяльності; незалежність, самостійність. У конструктивному аспекті - гнучкість / адаптивність навчальної діяльності до різних навчальних ситуацій, здатність до творчого перетворення навчальної діяльності, накопичення і передача індивідуального досвіду і перенесення ефективного досвіду в новий навчальний контекст, взаємодія і співпраця в процесі вирішення завдань навчальної діяльності.

Самостійна робота вимагає від студента сформованості певних якостей: визначення цілей самостійної діяльності; креативності мислення; наполегливості, цілеспрямованості в діяльності; можливості подолання труднощів; творчих здібностей, здатності самостійно робити вибір, приймати рішення; рефлексії власної пізнавальної і творчої діяльності.

Як дидактичне явище самостійна робота $\epsilon$, з одного боку, навчальним завданням, об’єктом діяльності; з другого - формою прояву відповідної діяльності пам'яті, мислення, творчої уяви, в результаті якої відбувається отримання студентом нових знань, поглиблення і розширення сфери дії вже отриманих знань, формування певних навичок і виробленні прийомів засвоєння.

Крім наявності особистісних якостей, готовність студента до самостійної діяльності з вивчення іноземної мови визначається:

1) наявністю базових навчальних навичок роботи за всіма видами мовленнєвої діяльності;

2) наявністю навичок перекладу i роботи зі словником i довідковою літературою;

3) умінням працювати з комп'ютерним програмним забезпеченням і Інтернетом.

Системою навчання можна вважати загальну модель навчального процесу, що відповідає певній методичній концепції, якою обумовлюється відбір матеріалу, мета, фрорми, зміст і засоби.

Сучасна педагогічна система спрямована на особистісно орієнтовану освіту, що вимагає впровадження в освітній процес інноваційних педагогічних технологій, які розробляються в дослідженнях А. Айзенберга, В. Астахова, С. Вітвицької,
Л. Воєводіна,
О. Л. Жук,
А. Лобанова,
$€$ Є. Полата,
І. Поліщук,
Є. Пометун, 
Н. Суворової, В. Шадрікова та інших.

Система навчання базується на наукових положеннях в лінгвістичному, психологічному та методичному плані, навчання іноземної мови реалізується за певною системою. Авторські колективи, розробляючи навчальні матеріали 3 вивчення англійської мови, використовують різні методичні концепції, що дає змогу розглядати їх як різні системи навчання [4, с. 4-10].

Методику можна охарактеризувати як сукупність методичних дій, які використовуються для найбільш доцільного здійснення процесу навчання, що приводить до успішного досягнення цілей навчання. Тобто виконується основне завдання методики - оптимальне управління процесом навчання. Методика викладання іноземних мов як наука має свою структуру, свої об’єкти і завдання [5, с. 60].

У сучасних методичних дослідженнях доцільно давати оцінку не тільки лінгвістичним здібностям учня, а і його творчому розвитку, становленню особистісної культури, цінностей та смислів, оволодінням засобами і способами різних видів діяльності за допомогою іноземної мови. Методична задача полягає в тому, щоб ссрормувати у студента здатність компетентно і конструктивно самостійно, автономно від викладача, розвивати в собі вміння користуватися мовою, що вивчається в текстовій діяльності за умови постійного саморозвитку та самовдосконалення особистості.

Сучасна методологічна технологія передбачає:

1. Припис способів діяльності (дидактичні процеси).

2. Умови, в яких ця діяльність повинна втілюватися (організаційні фоорми навчання).

3. Засоби здійснення цієї діяльності (система підготовки викладача до занять).

4. Для вибору дидактичного процесу в педагогічній технології використовуються поняття: алгоритм функціонування та алгоритм управління (В. В. Чечет).

Методологічна технологія, що застосовується при вивченні іноземної мови, передбачає поєднання застосування методичних приписів і розробок; застосування алгоритмів діяльності і особистого педагогічного досвіду, що дає змогу викладачеві передбачити різноманітні прояви освітніх ситуацій; здатність видозмінювати стереотипні педагогічні моделі на основі високої майстерності, методологічної культури, авторської інтерпретації теоретичних установок.

Методологічною сутністю самостійної роботи студента $є$ розвиток у нього міжпредметних, узагальнених знань і умінь, універсальних здібностей, способів пізнання і наукового дослідження.

У процесі вивчення іноземної мови формується іншомовна комунікативна компетентність, яка в контексті особистісно орієнтованої освіти $€$ системоутворюючим підходом, що сприяє становленню особистості і суб'єктності студентів. Змінюються мотиви освоєння іноземної мови: від власне комунікативних (розуміння інших і самовираження засобами іноземної мови) до профресійних, дослідницьких, кар'єрних.

Визначення цілей вдосконалення самостійної навчальної діяльності студентів при вивченні іноземної мови передбачають оптимізацію процесу навчання, актуалізацію та активізацію пошуку нових знань, розвиток творчого 
характеру освіти, підвищення якості засвоєння пропонованих навчальних програм. На кожному освітньому етапі (початковому і просунутому) конкретні завдання будуть різними.

Так, основними завданнями самостійної роботи на першому і другому роках навчання, крім завдань з власне мовної підготовки, $\epsilon$ формування таких особистісних якостей, як цілепокладання і здатність приймати рішення, наполегливість у навчанні, рефлексія і креативність мислення, оскільки вони визначають готовність студента до подальшої самоосвіти.

Форми організації самостійної роботи та розробка відповідних завдань визначаються завданнями певного етапу. Правильно організована самостійна робота під керуванням викладача дає змогу студентам першого року навчання виконати вимоги освітніх програм, досягти необхідного рівня комунікативної компетенції. Для індивідуалізації процесу навчання використовується великий банк тестових завдань з різних видів мовленнєвої діяльності; розроблені критерії відбору завдань як для розвитку конкретних видів мовної діяльності, так і для розвитку творчих здібностей і критичного мислення.

На просунутому етапі навчання змінюється характер і форма організації самостійної роботи: вирішується завдання вдосконалення навичок роботи 3 довідковою літературою, словниками, формуються вміння відбирати і аналізувати інформацію. Основними видами самостійної роботи $є$ підготовка і подання рефератів, проектів. Викладачами розробляються завдання для самостійної роботи, теми рефератів і доповідей, інструкції та методичні вказівки до виконання завдань, теми курсових робіт і вимоги до них, списки обов'язкової та додаткової літератури.

Таким чином, для забезпечення високого рівня методичної організації самостійної роботи студентів розробляються рекомендації методичного плану, що допомагають викладачам досягти ефективності в організації самостійної роботи студентів - встановлюються основні види робіт, визначається обсяг завдань, що виконуються, форми і норми контролю; постійно розробляються нові завдання для самостійної роботи студентів, коригуються і вдосконалюються вже існуючі. Ведуться пошуки нових фрорм організації самостійної роботи, досліджуються шляхи вдосконалення навчальної діяльності.

Необхідними умовами до завдань з організації самостійної роботи при вивченні іноземної мови $€$ : вмотивованість навчального завдання; чітка постановка пізнавальних завдань; алгоритм, метод виконання роботи, знання студентом способів її виконання; чітке визначення викладачем обсягу роботи, термінів ії подання; визначення видів консультаційної допомоги (консультації установчі, тематичні, проблемні); критерії оцінки; види і форми контролю.

Для забезпечення високої ефективності керованої самостійної роботи студентів з оволодіння іноземною мовою необхідно вирішити низку завдань, що стоять перед викладачами кафедри іноземних мов:

- розробка нормативів з визначення обсягів позааудиторної самостійної роботи для викладача і для студента; здійснення планування і контролю виконання;

- забезпечення правильного поєднання обсягів аудиторної та самостійної роботи; 
- забезпечення студента необхідними методичними матеріалами;

- посилення консультаційно-методичної ролі викладача;

- забезпечення можливості вільного спілкування між студентами, між студентами і викладачем іноземною мовою;

- перебудова традиційних форм навчальних занять.

Існуючі спеціальні центри самоосвіти (the study centre) сприяють ефрективній самоосвіті і можуть містити такі секції: а) бібліотека, що містить популярну, спеціальну та навчальну (course вooks) літературу, газети і журнали; б) відділ самоосвіти, що включає матеріали для самоосвіти з ключами для самоконтролю; в) комп'ютерна та відео- секції.

Підготовча робота здійснюється студентами в режимі самостійної роботи. Мовні засоби можуть освоюватися в режимі самостійної діяльності, заснованої на операціях, пов'язаних з використанням комп'ютера, організованих за алгоритмом заданої множини операцій. Основними перевагами комп'ютерних технологій $€$ можливість організації відкритого навчального мовного середовища, що наближається до реальної комунікації; конструктивно обумовлений індивідуалізований характер навчання з урахуванням різних рівнів володіння мовою. Наявність регульованого зворотного зв'язку, наочне представлення мовного матеріалу, об'єктивна оцінка результатів дій студентів надає великі можливості для подальшого аналізу роботи студента.

Навчальна діяльність студентів при роботі з комп'ютером може звільнити викладача від значної частини рутинної роботи (перевірка виконання окремих вправ, фронтальне опитування, представлення великого обсягу мовного матеріалу), що дасть змогу проводити аудиторне заняття більш ефективно, організовуючи режим активної комунікації - повноцінного людського спілкування, де засобами спілкування стає іноземна мова і культура країни, що вивчається.

Необхідною дидактичною умовою організації самостійної роботи є чітке управління всім ходом цієї роботи, яке полягає в цілеспрямованому проектуванні методичного забезпечення навчального процесу 3 метою оптимального засвоєння матеріалу студентами та оволодіння ними прийомами навчальної праці. У самостійній діяльності студентів можна виділити два взаємодоповнюючих компоненти: внутрішній та зовнішній.

Внутрішній компонент полягає в чіткому визначенні самими студентами предмета своєї діяльності, виділення мети цієї діяльності, виборі засобів і способів діяльності, визначенні засобів самоконтролю.

В процесі зростання самостійної роботи студентів відбувається становлення їх самоосвітніх здібностей, формуються можливості підтримування і підвищення в процесі самоосвіти рівня володіння іноземною мовою.

Зовнішній компонент самостійної роботи - це управління самостійною діяльністю студентів з боку викладача, що передбачає визначення цілей самостійної роботи студентів, ставлення викладачем усного або письмового завдання, спостереження за практичними діями студентів і надання їм за необхідності допомоги, роботу над помилками, контроль і аналіз результатів.

Таким чином, перед викладачами кафедр сучасних європейських мов стоять завдання формування мовної комунікативної компетенції студентів, розвитку особистісних якостей, розвитку загальних і спеціальних здібностей і вмінь, що 
забезпечують можливість подальшого самостійного оволодіння іноземною мовою.

Вищі навчальні заклади повинні надавати студентам можливість самостійно приймати рішення при виборі рівня складності завдання (залежно від рівня вимог), методів оволодіння матеріалом, особистісно й практично значущого змісту, а також неодмінно припускає необхідність висловлювати та захищати власну думку, виявляти самостійність у діях ("Всесвітня декларація про вищу освіту для XXI століття") [3].

Для сучасної професійної діяльності необхідний спеціаліст, спроможний оперативно приймати нешаблонні рішення, діяти самостійно, творчо. За правильної організації самостійна робота виступає засобом свідомого і міцного засвоєння знань студентами, має вирішальне значення для розвитку самостійності як однієї з провідних рис особистості фрахівця з університетською освітою, фрормуючи потребу в самостійному поповненні знань, при застосуванні методів і прийомів самоосвіти.

\section{Використана література:}

1. Богданова I. М. Педагогічна інноватика. Одеса : ТЕС, 2000. 148 с.

2. Вітвицька С. С. Основи педагогіки вищої школи. Київ : Центр навчальної літератури, 2003. 316 с.

3. Всемирная декларация о высшем образовании для XXI века: подходы и практические меры. Вестн. Высши. шк. 1999. № 3. С. 29-35.

4. Ляховицкий М. В. О некоторых базисных категориях методики обучения иностранным языкам. Иностранные языки в школе. 2013. № 8. С. 4-10.

5. Методика навчання іноземних мов і культур: теорія і практика : підручник для студ. класичних, педагогічних і лінгвістичних університетів / О. Б. Бігич, Н. Ф. Бориско, Г. Е. Борецька та ін. ; за загальн. ред. С. Ю. Ніколаєвої. Київ : Ленвіт, 2013. 590 с.

6. Осипчук Наталія. Вивчаймо англійську - тестуємо знання. Освіта. Всеукраїнський громадськополітичний тижневик. 2016. № 38-39. С. 5.

7. Педагогіка вищої школи : навч. посіб. / 3. Н. Курлянд, Р. І. Хмелюк, А. В. Семенова та ін. ; за ред. 3. Н. Курлянд. Київ : Знання, 2007. 495 с.

\section{References:}

[1] Bohdanova I. M. (2000). Pedahohichna innovatyka. Odesa : TES. $148 \mathrm{~s}$.

[2] Vitvytska S. S. (2003). Osnovy pedahohiky vyshchoi shkoly. Kyiv : Tsentr navchalnoi literatury. - $316 \mathrm{~s}$.

[3] Vsemyrnaia deklaratsyia o vysshem obrazovanyy dlia KhKhI veka: podkhody y praktycheskye mery. Vestn. Vyssh. shk. 1999. № 3. S. 29-35.

[4] Liakhovytskyi M. V. (2013). O nekotorykh bazysnykh katehoryiakh metodyky obuchenyia ynostrannym yazykam. Ynostrannye yazyky v shkole. № 8. S. 4-10.

[5] (2013). Metodyka navchannia inozemnykh mov i kultur: teoriia i praktyka: pidruchnyk dlia stud. klasychnykh, pedahohichnykh i linhvistychnykh universytetiv / Bihych O. B., Borysko N. F., Boretska H. E. ta in. ; za zahaln. red. S. Yu. Nikolaievoi. Kyiv : Lenvit. 590 s.

[6] Osypchuk Nataliia. Vyvchaimo anhliisku - testuiemo znannia. Osvita. Vseukrainskyi hromadskopolitychnyi tyzhnevyk. 2016. № 38-39. S. 5.

[7] (2007). Pedahohika vyshchoi shkoly : navch. posib. / Z. N. Kurliand, R. I. Khmeliuk, A. V. Semenova ta in. ; za red. Z. N. Kurliand. Kyiv : Znannia. 495 s.

БРЕСЛАВЕЦН. А. Методические действия в осуществлении процесса обучения иностранных языков с акцентом на самостоятельную работу студентов.

Фактор личностного роста человека в ХХІ выходит на первый план мотивачионных устремлений молодого поколения: свобода передвижения по всему миру, взаимопроникновение экономик, международное разделение труда, интенсификащия процесса торговли и др. Это 
является вызовами современности, резко стимулирующими изучение иностранных языков, требующиим глубоких и качественных изменений преподавания иностранного языка в средней и высшей школе.

В современных условиях самостоятельность становится профессионально необходимым качеством личности любого специалиста. Таким образом, подготовка будущих специилистов в высшем учебном заведении должны ориентироваться на формирование у студентов этого качества. Выражение самостоятельности личности - поступки, действия, высказывание, оценка личности относительно как тех, кто окружает, так и самой себя; самостоятельность отображается в результатах деятельности, в характере становления $к$ окружающей среде и направленности поведения. В свете современной образовательной концепџии особого смысла приобретает процесс самообразования как средства развития творческой индивидуальности, сохранение человеческого достоинства, способ "встраивания себя" в сочиокультурный прочесс, в общество.

В условиях реформирования национальной системы высмего образования вопросы научной организаџии учебно-воспитательного проиесса приобретают особую значимость, так как они определяют не только качество подготовки специалистов, но и обеспечивают будущее экономики. Самостоятельная работа студента под контролем и без контроля преподавателя должна рассматриваться как важная часть всех составляющих учебного прочесса, обеспечиваться учебными и научными разработками, материально-технической базой, иметь высокую мотивацию.

Ключевые слова: методологическая технология, самостоятельная работа студентов, субъектность, иелеполагание, планирование, саморегуляиия действий, самоконтроль.

\section{BRESLAVETS N. O. Methodical actions in implementing the process of learning foreign languages with the accent on independent work of students.}

The human growth factor in XXI century comes to the forefront of the motivational aspirations of the young generation: freedom of movement around the world, interpenetration of economies, the international division of labor, the intensification of the trade process, etc. The above mentioned ones are challenges of our time, sharply stimulating the study of foreign languages, requiring profound and qualitative changes in the teaching of a foreign language in secondary and high school.

In modern conditions independence becomes professionally necessary quality of personality of any specialist. Thus, the training of future specialists in higher education should be guided by the formation of students of this quality. Expression of personality autonomy - actions, actions, statements, assessment of personality in relation to both those around him and himself; independence is manifested in the results of activity, in the nature of becoming to the environment and the orientation of behavior. In the light of the modern educational concept, the process of self-education as a means of developing creative individuality, preserving human dignity, a way of "embedding oneself" into the socio-cultural process, into society, acquires a special meaning.

The issues of the scientific organization of the educational process are of particular importance in the context of reforming the national system of higher education. They not only determine the quality of training, but also ensure the future of the economy. Independent work of a student under the control and without control of the teacher should be considered as an important part of all the components of the educational process, which is provided with educational and scientific developments, material and technical basis.

Keywords: methodological technology, independent work of students, subjectivity, goal setting, planning, self-regulation of actions, self-control. 